\title{
Retirement Portfolio Realities: The Mathematics of Survival
}

\author{
Craig L. Israelsen
}

\begin{abstract}
This paper deals with several important retirement questions: "How much money do I need in my investment portfolio at the start of retirement?" and "How much can I safely withdraw from my investment portfolio during the retirement years?" This paper introduces the novel concept of "RAM" or Retirement Account Multiple. The mathematics of income replacement in retirement are demonstrated and the historical survival of two different retirement portfolios are reviewed over a 90-year period from 1926-2015.
\end{abstract}

Index Terms-Diversified retirement portfolio, income replacement in retirement, retirement account multiple (RAM), withdrawal rate.

\section{INTRODUCTION}

This research abstract deals with several important retirement questions: "How much money do I need in my investment portfolio at the start of retirement?" and "How much can I safely withdraw from my investment portfolio during the retirement years?"

\section{RESEARCH QUESTIONS}

While it's not possible to provide a precise answer to the two questions above that will apply to everyone's unique situation, it is possible to provide general guidance that can assist financial advisors and individual investors as they navigate their preparation for retirement and manage their financial resources during retirement.

\section{A. Question \#1}

The first question is: "How much money do I need in my investment portfolio at the start of retirement?" This is one aspect of retirement portfolios that is surprisingly straightforward. The amount of your pre-retirement income that you will be able to replace while in retirement is directly (and mathematically) related to your retirement portfolio account balance (which I'll be referring to as the Retirement Account Multiple or RAM). The connecting tissue between these two variables is your initial withdrawal rate-or the percentage of your retirement account balance that you are withdrawing in the first year of your retirement [1], [2].

For instance, if your pre-retirement salary was $\$ 100,000$ and you have accumulated a retirement account balance of $\$ 1,200,000$ you have a RAM (Retirement Account Multiple)

Manuscript received on February 25, 2017; revised May 17, 2017.

Craig L. Israelsen is on the faculty of the Woodbury School of Business, Utah Valley University, Orem, Utah, 84058 (e-mail: craig@7TwelvePortfolio.com). of 12x. A 4\% withdrawal rate from your retirement account balance of $\$ 1,200,000$ in the first year of retirement equals $\$ 48,000$ - which is a $48 \%$ replacement of your preretirement income of $\$ 100,000$. (Understandably, you may have other retirement income from other sources).

RAM $* \%$ Withdrawal Rate $=\%$ Income Replacement

Various combinations of RAM and withdrawal rate are summarized in Table I below. For example, a RAM of 7x that is paired with a $3 \%$ initial withdrawal rate will allow you to receive (in the first year of retirement) $21 \%$ of your pre-retirement annual salary

The figures in the grey portion of Table I represent the percentage of pre-retirement income being replaced in the first year of retirement. Numbers in red represent income replacement ratios of below $60 \%$. The figures in green represent income replacement of $60 \%$ and higher. For many retirees, the replacement ratios in red may not provide adequate retirement income. Red numbers are caused by a RAM that is too low and/or a withdrawal rate that is too small.

TABLE I. INCOME REPLACEMENT IN RETIREMENT BASED ON RAM AND WITHDRAWAL RATE

\begin{tabular}{|c|c|c|c|c|c|c|}
\hline \multicolumn{7}{|c|}{ \% Income Replacement in Retirement } \\
\hline \multirow{2}{*}{$\begin{array}{c}\text { Retirement } \\
\text { Account Multiple } \\
\text { of Final Salary } \\
\text { (RAM) }\end{array}$} & \multicolumn{6}{|c|}{ Initial Withdrawal Rate $(\%)$ in Retirement } \\
\hline & $2 \%$ & $3 \%$ & $4 \%$ & $5 \%$ & $6 \%$ & $7 \%$ \\
\hline $5 x$ & $10 \%$ & $15 \%$ & $20 \%$ & $25 \%$ & $30 \%$ & $35 \%$ \\
\hline $7 \mathbf{x}$ & $14 \%$ & $21 \%$ & $28 \%$ & $35 \%$ & $42 \%$ & $49 \%$ \\
\hline $10 x$ & $20 \%$ & $30 \%$ & $40 \%$ & $\mathbf{5 0 \%}$ & $60 \%$ & $70 \%$ \\
\hline $12 x$ & $24 \%$ & $36 \%$ & $48 \%$ & $60 \%$ & $72 \%$ & $84 \%$ \\
\hline $15 x$ & $30 \%$ & $45 \%$ & $60 \%$ & $75 \%$ & $90 \%$ & $105 \%$ \\
\hline $20 x$ & $40 \%$ & $60 \%$ & $80 \%$ & $100 \%$ & $120 \%$ & $140 \%$ \\
\hline $25 x$ & $50 \%$ & $75 \%$ & $100 \%$ & $125 \%$ & $150 \%$ & $175 \%$ \\
\hline
\end{tabular}

\section{B. Question \#2}

The second question - and it is a big one-pertains to how many years our portfolio will last [3]-[9]. To address that question several different retirement portfolios have been evaluated over the past 90 years. Only four U.S-based asset classes have performance data going back to 1926 (large cap US stock, small cap US stock, US bonds, and US cash).

\section{Methodology AND Data SOURCES}

The first portfolio is a conservative retirement model that 
consists of $25 \%$ US stock and $75 \%$ fixed income (specifically $15 \%$ large cap US stock, $10 \%$ small cap US stock, $55 \%$ bonds and $20 \%$ cash). The second retirement portfolio being evaluated is a moderate risk $65 \%$ stock $/ 35 \%$ fixed income model (specifically $40 \%$ large cap US stock, $25 \%$ small cap US stock, $25 \%$ bonds, and $10 \%$ cash).

Both four-asset portfolios were rebalanced at the end of each year back to the prescribed allocations [10]. The performance of large cap US stock was represented by the S\&P 500 Index, small cap US stock by the Ibbotson Small Stock Index from 1926-1978 and the Russell 2000 Index from 1979-2015, US bonds by the Ibbotson US Intermediate Government Bond Index from 1926-1975 and the Barclay's Capital Aggregate Bond Index from 1976-2015, and US cash was represented by 90 -day Treasury Bills.

Over the 90-year period from January 1, 1926 to December 31, 2015 there were 56 rolling 35-year periods. Both portfolios were tested under various initial withdrawal rates and a 3\% annual cost-of-living-adjustment (COLA) to determine how often they were able to last for at least 35 years (simulating the 35-year period between ages 65 and 100 for a retiree). "Success rate" refers to how often each retirement portfolio lasted at least 35 years or longer over the past 90 years.

\section{A. How Much Can I Safely Withdraw?}

We will assume that a retiree is attempting to replace about $60 \%$ of their pre-retirement income from their retirement portfolio via annual withdrawals from their retirement portfolio (as highlighted in yellow in Table II). (If the retiree's ultimate goal is to replace $100 \%$ of their pre-retirement income the remaining needed income replacement (40\% in this case) will need to come from other retirement income sources such as social security, pension(s), rental income, etc.).

A $60 \%$ income replacement is not possible if the retiree's RAM is $5 x$ or $7 x$. If, however, the retiree has an account balance that is 10x larger than their pre-retirement income (a RAM of 10x) they can replace $60 \%$ of their pre-retirement income if they employ a $6 \%$ withdrawal rate (as calculated by $\mathrm{RAM} *$ Withdrawal rate $=\%$ Income Replacement).

\section{RESULTS}

In Table II we see several combinations that can produce a $60 \%$ income replacement: a 10x RAM and a $6 \%$ withdrawal rate, a 12x RAM and a 5\% withdrawal rate, a 15x RAM and a 4\% withdrawal rate, and a 20x RAM with a $3 \%$ withdrawal rate (all highlighted in yellow).

If a $3 \%$ withdrawal rate is used, both portfolios had a historical success rate of $100 \%$. A 3\% COLA was assumed for all the scenarios. If a $4 \%$ withdrawal rate is used, the $25 / 75$ portfolio had success $93 \%$ of the time and the $65 / 35$ portfolio $98 \%$ of the time. At a $5 \%$ withdrawal rate, the $25 / 75$ portfolio lasted at least 35 years in only $59 \%$ of the historical 35 -year periods, whereas the $65 / 35$ portfolio had success $91 \%$ of the time. A $6 \%$ withdrawal rate led to a $34 \%$ success rate for the $25 / 75$ portfolio and an $87 \%$ success rate for the $65 / 35$ portfolio. The green shaded boxes represent income replacement of $60 \%$ or higher.

The key to using Table II is to identify your RAM and the percentage income replacement that it provides at various withdrawal rates. Finally, check the historical success rate of the withdrawal rate you have selected. Black font success rates indicate $90 \%$ or higher, while red font success rates indicate historical success rates below 90\%. Low success rates indicate you may need to consider a lower withdrawal rate (which will cause a lower income replacement).

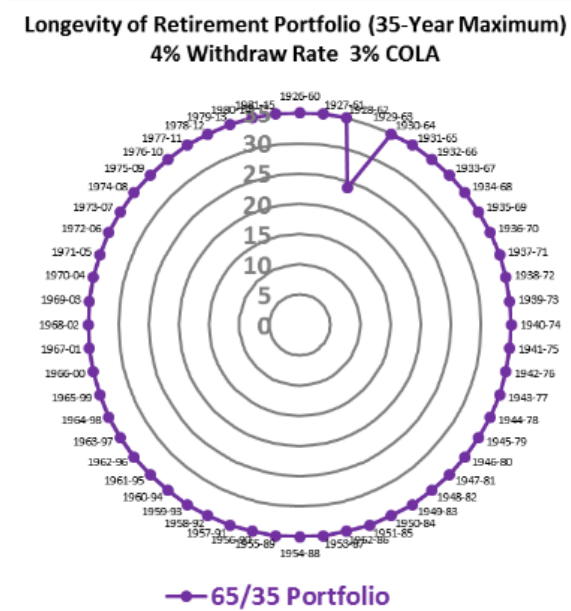

Fig. 1. Retirement Portfolio Longevity with a $65 / 35$ Portfolio at a $4 \%$ Withdraw Rate and 3\% Annual COLA: 90-Year Period from 1926-2015.

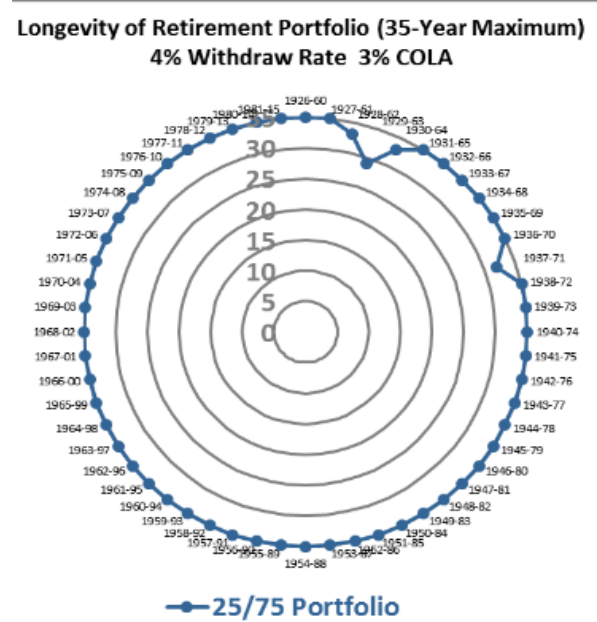

Fig. 1a. Retirement Portfolio Longevity with a 25/75 Portfolio at a $4 \%$ Withdraw Rate and 3\% Annual COLA: 90-Year Period from 1926-2015.

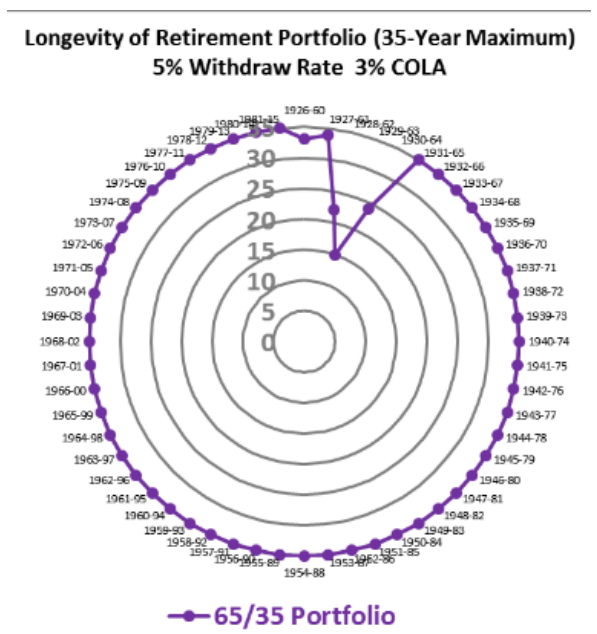

Fig. 2. Retirement Portfolio Longevity with a 65/35 Portfolio at a 5\% Withdraw Rate and 3\% Annual COLA: 90-Year Period from 1926-2015. 
Longevity of Retirement Portfolio (35-Year Maximum) $5 \%$ Withdraw Rate $3 \%$ COLA

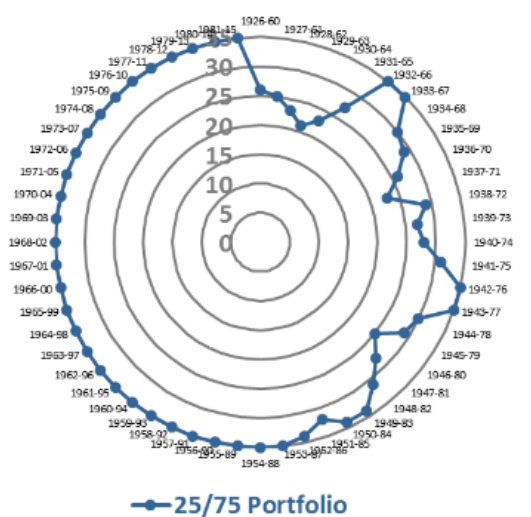

Fig. 2a. Retirement Portfolio Longevity with a 25/75 Portfolio at a 5\% Withdraw Rate and 3\% Annual COLA: 90-Year Period from 1926-2015.

Figs. 1-3 graphically depict the longevity of the two retirement portfolios at various withdrawal rates and a $3 \%$ annual COLA. The outer ring in each figure represents at least a 35-year survival period, while the inner rings indicate shorter survival periods. Each dot represents a 35-year time frame (1926-1960, 1927-1961, etc.).

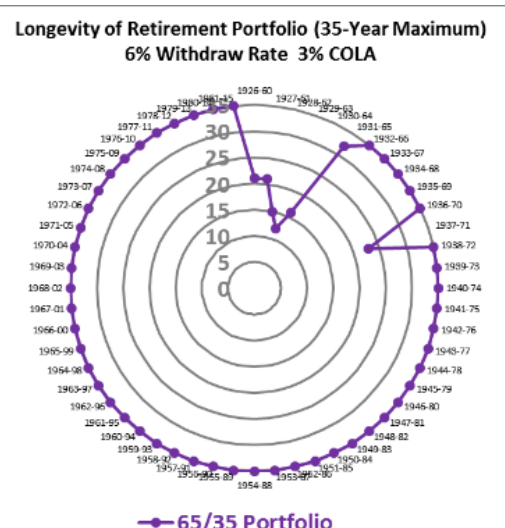

Fig. 3. Retirement Portfolio Longevity with a 65/35 Portfolio at a $6 \%$ Withdraw Rate and 3\% Annual COLA: 90-Year Period from 1926-2015

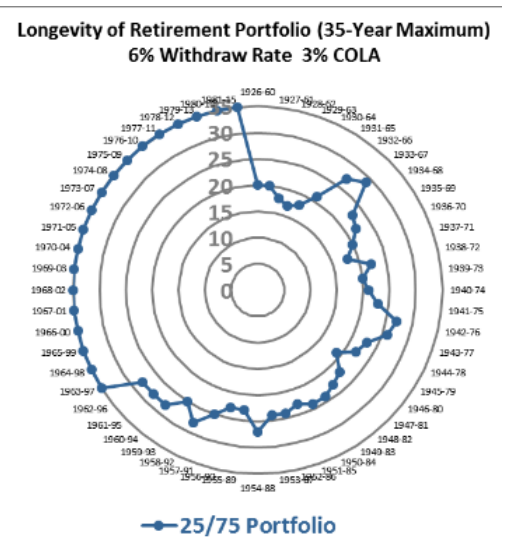

Fig. 3a. Retirement Portfolio Longevity with a $25 / 75$ Portfolio at a $6 \%$ Withdraw Rate and 3\% Annual COLA: 90-Year Period from 1926-2015

\section{DISCUSSION AND IMPLICATIONS}

This analysis illustrates the importance of maintaining a diversified portfolio during the retirement years-which could easily span three decades. Moreover, a retirement portfolio that has a commitment to growth asset classes is more likely to survive for 35 years-particularly if the retiree uses an initial withdrawal rate of $4 \%$ or higher.

TABLE II: RETIREMENT PORTFOLIO MATH AND HistoRICAL SUCCESS RATES (3\% COLA ASSUMED)

\begin{tabular}{|c|c|c|c|c|c|c|}
\hline \multicolumn{7}{|c|}{ Retirement Income Replacement, Portfolio Withdrawal Rate, } \\
and Historical Success Rate \\
(3\% COLA assumed)
\end{tabular}

* 4-Asset 25/75 Portfolio:

$15 \%$ Large Cap US Stock, $10 \%$ Small Cap US Stock, 55\% US Bonds, 20\% Cash

** 4-Asset 65/35 Portfolio: 40\% Large Cap US Stock, 25\% Small Cap US Stock, 25\% US Bonds, $10 \%$ Cash

If an investor has accumulated a 20x retirement portfolio they have the "luxury" of using a lower withdrawal rate to achieve their needed income replacement during the retirement years. A lower withdrawal rate permits a more conservative asset allocation in the design of the retirement portfolio.

For example, if the retiree uses a $3 \%$ initial withdrawal rate (based upon a large RAM) this analysis demonstrates that a conservative $25 / 75$ portfolio had a $100 \%$ rate of success rate in lasting at least 35 years during retirement. Thus, as the RAM is higher the retiree will be able to employ a more conservative asset allocation in their retirement portfolio which effectively reduces the volatility of their retirement portfolio without diminishing the likelihood of the portfolio surviving at least 35 years.

In each Fig. the outer ring represents at least a 35-year survival period, inner rings indicate shorter periods of survival. Each dot represents a 35-year time frame (19261960, 1927-1961, etc.).

\section{REFERENCES}

[1] W. P. Bengen, "Determining withdrawal rates using historical data," Journal of Financial Planning, vol. 7, pp. 171-180, 1994.

[2] W. P. Bengen, "Baking a withdrawal plan 'layer cake' for your retirement clients," Journal of Financial Planning, vol. 19, no. 8: pp. 44-51, 2006.

[3] P. L. Cooley, C. M. Hubbard, and D. T. Waltz. "Retirement Savings: Choosing a Withdrawal Rate that is Sustainable," Journal of the American Association of Individual Investors, vol. 20: pp. 16-21, 1998.

[4] P. L. Cooley, C. M. Hubbard, and D. T. Waltz. "A comparative analysis of retirement portfolio success rates: Simulation versus 
overlapping periods," Financial Services Review, vol. 16: pp. 115$128,2003$.

[5] J. C. Jarrett and T. Stringfellow. "Optimum withdrawals from an asset pool," Journal of Financial Planning, vol. 13, no 1, pp. 80-93, 2000.

[6] W. D. Pfau, "An international perspective on safe withdrawal rates from retirement savings: The demise of the 4 percent rule?" Journal of Financial Planning, 23, 12 (December): pp. 52-61, 2010.

[7] W. D. Pfau, "Can we predict the sustainable withdrawal rate for new retirees?" Journal of Financial Planning, vol. 24, no. 8, pp. 40-47, August 2011.

[8] J. Spitzer, J. Strieter, and S. Singh. "Guidelines for withdrawal rates and portfolio safety during retirement," Journal of Financial Planning, vol. 20, no. 10, pp. 52-59, October 2007.

[9] A. Tezel, "Sustainable retirement withdrawals," Journal of Financial Planning, vol. 17, no. 7: pp. 52-57, 2004.

[10] P. Kaplan, "Asset Allocation with annuities for retirement income management," The Journal of Wealth Management, vol. 8, no. 4, pp. 27-40, Spring 2006.

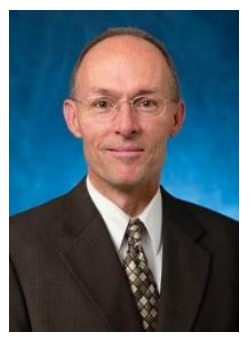

Craig L. Israelsen was born in Palo Alto, California in 1959. He holds a Ph.D. in family resource management from Brigham Young University, Provo, Utah in 1990, a M.S. degree in agricultural economics from Utah State University, Logan, Utah in 1984, and B.S. degree in agribusiness from Utah State University in 1983.

He teaches in the Personal Financial Planning Program in the Woodbury School of Business at Utah Valley University, Orem, Utah. He has also taught at Brigham Young University and the University of Missouri. Primary among his research interests is the analysis of mutual funds and the design of investment portfolios.

Dr. Israelsen writes monthly for Financial Planning Magazine (New York, NY) and is a regular contributor to Horsesmouth.com. His research has also been published in the Journal of Indexes, Journal of Financial Planning, Journal of Asset Management (U.K.), Journal of Performance Measurement, Asia Financial Planning Journal (Singapore), Journal of Family and Economic Issues, and Financial Counseling and Planning. 